\title{
Studi Farmakokinetika Teofilina Setelah Pemberian Oral Dosis Tunggal Tablet Teofilina dan Aminofilina Lepas Kendali pada Subyek Normal
}

\author{
Nani Parfati ${ }^{1}$, Jenny Chandra ${ }^{1}$, Tan Kiauw Sia ${ }^{1}$, Doddy de Queljoe ${ }^{1}$, dan Thomas Kardjito ${ }^{2}$ \\ ${ }^{1}$ Departemen Farmasetika, Fakultas Farmasi Universitas Surabaya, Surabaya \\ 2 Fakultas Kedokteran Universitas Airlangga, Surabaya
}

Korespondensi: Nani Parfati

Email:nani_parfati@staff.ubaya.ac.id

\begin{abstract}
ABSTRAK: Telah dilakukan penelitian untuk mempelajari farmakokinetika dari teofilina setelah pemberian oral dosis tunggal tablet teofilina dan aminofilina lepas kendali pada subyek normal. Tablet teofilina (dosis $300 \mathrm{mg}$ ) dan aminofilina (dosis $350 \mathrm{mg}$ ) lepas kendali diberikan dalam bentuk oral dosis tunggal, pada pria normal (20-30 tahun, 50-75 kg), tidak merokok, dengan fungsi paruparu, hati, ginjal dan jantung normal. Kadar teofilina serum ditentukan dengan metode Flourescence Polarization Immunoassay (FPIA). Parameter farmakokinetika yang diamati meliputi: $t$ maks, $\mathrm{Cp}$ maks, AUC, tetapan laju absorpsi (Ka) dan eliminasi (K) serta t $1 / 2$ eliminasi. Hasil penelitian menunjukkan bahwa profil kurva kadar teofilina serum terhadap waktu untuk tablet teofilina (AUC=97,56 $\mu \mathrm{g} / \mathrm{ml} \mathrm{jam}, \mathrm{Cp}$ maks $=5,83 \mu \mathrm{g} / \mathrm{ml}, \mathrm{Ka}=0,209 \mathrm{jam}^{-1}$, t maks $=4 \mathrm{jam}, \mathrm{K}=0,080 \mathrm{jam}^{-1}$, dan $\mathrm{t} 1 / 2=8,87 \mathrm{jam}$ ) dan aminofilina (AUC=121,93 $\mathrm{g} / \mathrm{ml}$ jam, Cp maks=6,70 $\mu \mathrm{g} / \mathrm{ml}, \mathrm{Ka}=0,239 \mathrm{jam}^{-1}, \mathrm{t}$ maks $=6,8 \mathrm{jam}$, $\mathrm{K}=0,061 \mathrm{jam}^{-1}$, dan $\mathrm{t}^{1} / 2=11,51 \mathrm{jam}$ ) lepas kendali sesuai dengan profil farmakokinetika sediaan lepas kendali pada umumnya.
\end{abstract}

Kata kunci: teofilina; aminofilina; tablet lepas kendali; farmakokinetik

\begin{abstract}
A study has been conducted to evaluate the pharmacokinetics of theophylline after oral admi-nistration of a single dose of theophylline and aminophiline controlled release tablet in normal subjects. Controlled release tablets of theophylline (dose $300 \mathrm{mg}$ ) and aminophiline (dose $350 \mathrm{mg}$ ) were given in single oral doses, in normal men (20-30 years, 50-75 kg), not smoking, with normal function of lung, liver, kidney, and heart. Serum theofiline level was determined by Flourescence Polarization Immunoassay (FPIA) method. The pharmacokinetic parameters observed included: tmax, Cmax, AUC, constant of absorption (Ka) and elimination rate $(\mathrm{K})$ as well as $t^{1 / 2}$ elimination. The results showed that the profile of the serum theophylline content vs time for theophyline $(A U C=97.56 \mu \mathrm{g} / \mathrm{ml}$ hour, $C$ $\max =5.83 \mu \mathrm{g} / \mathrm{ml}, \mathrm{Ka}^{2}=0.209 \mathrm{hour}^{-1}, \mathrm{t} \max =4$ hours, $K=0.080$ hour $^{-1}$, and $\mathrm{t}^{1} 1 / 2=8.87$ hours) and aminophiline $\left(A U C=121.93 \mu \mathrm{g} / \mathrm{ml}\right.$ hour, $C \max =6.70 \mu \mathrm{g} / \mathrm{ml}, \mathrm{Ka}=0.239$ hour $^{-1}, t$ max=6.8 hours, $K=0.061$ hour $^{-1}$, and $t^{1} / 2=11.51$ hours) controlled release tablets was in accordance with the pharmacokinetics profile of generally controlled release dosage forms.
\end{abstract}

Keywords: theophylline; aminophiline; controlled release tablet; pharmacokinetics 


\section{Pendahuluan}

Keberhasilan suatu terapi dengan obat, ditentukan antara lain oleh rancangan pengaturan dosisnya. Suatu aturan dosis dirancang dengan mempertimbangkan faktor-faktor: fisiologik, patofisiologik, farmakokinetik serta kebiasaan penderita [1]. Pada beberapa kondisi, obat diberikan pada suatu aturan dosis ganda yang dimaksudkan untuk memperpanjang aktivitas terapetik. Tetapi, pada cara tersebut terdapat beberapa kendala, yaitu adanya fluktuasi dan akumulasi kadar obat dalam darah yang mengakibatkan pengobatan kurang efektif. Produk obat dengan pelepasan terkendali dirancang untuk menghasilkan efek klinik yang maksimal dengan mempertahankan kadar obat dalam darah pada rentang terapetik, fluktuasi dan akumulasi diperkecil. Suatu rancangan sediaan farmasi dimana pelepasan obat dibuat menjadi order ke nol dan dengan mengatur laju absorpsi yang sama dengan laju eliminasi adalah bekal untuk dapat mempertahankan kadar obat dalam darah. Produk obat diformulasikan agar proses absorpsi tidak dipengaruhi oleh $\mathrm{pH}$, makanan dan kandungan zat-zat dalam semua bagian saluran cerna $[1,2,3]$.

Teofilina merupakan obat bronchodilator yang digunakan pada penderita asma; kadar terapetik teofilina dalam serum 5-20 $\mu \mathrm{g} / \mathrm{ml}$ dan efek toksik mulai terlihat di atas kadar $20 \mu \mathrm{g} / \mathrm{ml}$. Dalam praktek teofilina diberikan dalam bentuk dosis ganda sehingga rancangan dosis yang tepat sangat diperlukan dan rancangan produk dalam bentuk pelepasan terkendali adalah salah satu solusinya. Berdasarkan latar belakang tersebut maka tujuan penelitian ini adalah untuk menganalisis parameter farmakokinetika teofilina dalam bentuk pelepasan terkendali tablet teofilina dan aminofilina. Parameter farmakokinetik teofilina yang diamati adalah: luas area di bawah kurva (AUC), kadar obat mencapai maksimum (Cp maks), waktu obat mencapai puncak ( $\mathrm{t}$ maks), tetapan laju absorpsi (ka), tetapan laju eliminasi $(\mathrm{K})$, waktu paruh eliminasi ( $\mathrm{t} 1 / 2)$, dan waktu okupansi obat. Dengan mengetahui profil farmakokinetika teofilina tersebut dapat dipakai untuk pertimbangan di dalam pengaturan dosis $[4,5]$.

\section{Bahan, Alat dan Metode}

\subsection{Bahan}

Bahan yang digunakan dalam penelitian ini antara lain: Tablet teofilina $300 \mathrm{mg}$ lepas kendali, Lot. No. NCF9259A; Tablet aminofilina 350 mg lepas kendali, No. Batch: A1G655B; Heparin injeksi (Leo), TDx teofilina reagent pack (Abbot Laboratories, USA) terdiri dari pereaksi, kalibrator dan larutan kontrol, dapar pengawet.

\subsection{Alat}

Alat yang digunakan dalam penelitian ini antara lain: Flourescence Polarization Analyzer, $\mathrm{Cu}$ vette, Sample cartridge, Karosel (TDx Automated Abbot Laboratories, USA), Clinical centrifuge (Heraeus Sepatech); Refrigeration Unit (Sanyo type HF-1208) [6].

\subsection{Metode}

\subsubsection{Subyek}

Subyek penelitian adalah 9 orang pria sehat (20-30 tahun, 50-65 Kg) dimana 4 orang diberi tablet teofilina dan 5 orang diberi tablet aminofilina, bukan perokok, yang telah setuju menjadi sukarelawan. Tidak mengalami kelainan darah, saluran cerna, fungsi paru, ginjal, jantung dan hati. Setiap sukarelawan menjalani pemeriksaan klinis faal hati (SGOT, SGPT, bilirubin total dan albumin urine), serta faal ginjal (serum kreatinin, BUN, asam urat, protein total, alkali phospatase, serum kolesterol) [7].

\subsubsection{Protokol}

Satu minggu sebelum penelitian, subyek tidak diperbolehkan minum obat apapun terutama yang dapat mengganggu analisis penetapan kadar teofilina, juga makanan yang mengandung xantin. Sebelum perlakuan subyek berpuasa semalam (lebih dari 10 jam). Pada pagi hari, $1 / 2$ jam sebelum pemberian obat, subyek diambil darahnya dari vena cubiti selanjutnya diberi 1 tablet teofilina atau aminofilina disertai air $200 \mathrm{ml}$. Darah subyek diambil selang waktu $1 / 2,1,1 \frac{1}{2}, 2,4,6,10,12,14$ dan 16 jam. Untuk tablet aminofilina, pengambilan darah 
pada subyek dilanjutkan sampai 24, 28, 32 dan 36 jam setelah obat diberikan. Tiga jam setelah pemberian obat subyek mendapatkan makanan ringan dan satu jam kemudian diberi makan dengan menu seragam. Selama percobaan subyek tidak diperbolehkan makan atau minum yang dapat mengganggu penetapan kadar teofilina. Sebelum ditetapkan kadar teofilinanya, sampel darah dibiarkan 1 jam dan disentrifuge, serum digunakan untuk penetapan kadar. Apabila sampel tidak dapat ditetapkan pada hari itu, sampel disimpan dalam keadaan beku $[8,9]$.

\subsubsection{Penetapan kadar teofilina dalam serum darah.}

Penetapan kadar teofilina dalam serum darah dilakukan dengan metode Flourescence Polarization Immunoassay (FPIA). Prinsip dasar metode ini adalah kompetisi antara antigen berlabel fluorescence (teofilin fluorescence tracer) dengan antigen tak berlabel (teofilina dalam serum darah) dengan memperebutkan "binding site" yang terbatas pada molekul antibodi, kadar teofilina didapatkan dari kurva probit log [6].

\section{Hasil dan Pembahasan}

Hasil penelitian yang diperoleh adalah kadar teofilina dalam serum pada pemberian tablet teofilina dan aminofilina dapat dilihat pada Tabel 1 dan 2 dimana kadar teofilina yang didapat dari kurva probit log sesuai prosedur; harga parameter farmakokinetika (AUC, Cp maks, t maks, $\mathrm{K}$ dan $\mathrm{t} 1 / 2$ ) untuk pemberian tablet teofilina dan aminofilina pelepasan terkendali dapat dilihat pada Tabel 3 dan 4; kurva kadar teofilina terhadap waktu pada pemberian tablet teofilina dari keempat subyek dan pada pemberian tablet aminofilina pada kelima subyek dapat dilihat pada Gambar 1 dan 2.

Dari kurva kadar teofilina terhadap waktu (Gambar 1 dan 2) dapat dilihat bahwa profil farmakokinetikanya sesuai dengan profil farmakokinetika sediaan pelepasan terkendali, yaitu kadar teofilina dalam serum dapat dipertahankan, penurunan kadar obat dalam serum pada fase pasca absorpsi tidak tajam. Tetapan laju absorpsi yang dihitung dengan menggunakan metode Wagner-Nelson menunjukkan absorpsi order nol, yaitu laju absorpsi konstan (Gambar 3 dan Tabel $5,6)[4]$.

Waktu obat mencapai kadar maksimum dibandingkan pemberian tablet teofilina sediaan konvensional, terlihat lebih lambat dan kadar obat mencapai puncak juga lebih rendah [1]. Dari data kadar teofilina dalam serum (pemberian tablet teofilina dan aminofilina pelepasan terkendali) terlihat bahwa sebagian besar berada dalam rentang kadar terapetik (MEC 5-20 $\mu \mathrm{g} / \mathrm{ml}$ ) [5],

Tabel 1. Kadar teofilina serum dari masing-masing subyek pada pemberian tablet teofilina pelepasan terkendali dosis $300 \mathrm{mg}$

\begin{tabular}{cccccc}
\hline & & \multicolumn{5}{c}{ Kadar $(\boldsymbol{\mu g} / \mathbf{m l})$} \\
\cline { 3 - 6 } No. & Waktu (jam) & \multicolumn{4}{c}{ Subyek } \\
\cline { 3 - 6 } & & KW & DK & SC & WG \\
\hline 1. & 0,5 & 0,44 & 0,45 & 2,72 & 0,57 \\
2. & 1,0 & 1,01 & 2,40 & 2,19 & 2,38 \\
3. & 1,5 & 2,42 & 3,56 & 2,94 & 3,03 \\
4. & 2,0 & 3,03 & 3,96 & 3,17 & 3,65 \\
5. & 4,0 & 7,15 & 5,03 & 3,96 & 7,15 \\
6. & 6,0 & 6,95 & 4,67 & 3,86 & 6,99 \\
7. & 10,0 & 5,35 & 3,50 & 3,65 & 4,70 \\
8. & 12,0 & 4,56 & 2,99 & 3,32 & 3,39 \\
9. & 14,0 & 3,85 & 2,52 & 2,95 & 2,84 \\
10. & 16,0 & 3,23 & 2,10 & 2,61 & 2,41 \\
\hline
\end{tabular}


Tabel 2. Kadar teofilina serum dari masing-masing subyek pada pemberian tablet aminopilina pelepasan terkendali dosis $350 \mathrm{mg}$

\begin{tabular}{ccccccc}
\hline & & \multicolumn{5}{c}{ Kadar $(\boldsymbol{\mu g} / \mathbf{m l})$} \\
\cline { 3 - 6 } No. & Waktu (jam) & \multicolumn{5}{c}{ Subyek } \\
\cline { 3 - 6 } & & FR & WJ & RR & WB & RK \\
\cline { 3 - 6 } 1. & 0,5 & 1,72 & 0,72 & 1,08 & 0,78 & 0,83 \\
2. & 1,0 & 2,94 & 1,93 & 2,60 & 1,78 & 1,42 \\
3. & 1,5 & 3,55 & 2,52 & 3,13 & 2,79 & 2,13 \\
4. & 2,0 & 4,22 & 3,59 & 3,85 & 3,87 & 3,12 \\
5. & 4,0 & 6,21 & 4,88 & 6,68 & 6,25 & 4,43 \\
6. & 6,0 & 6,49 & 5,35 & 7,30 & 7,73 & 4,92 \\
7. & 8,0 & 6,63 & 5,26 & 7,20 & 7,19 & 6,48 \\
8. & 10,0 & 6,56 & 4,37 & 5,95 & 4,78 & 6,21 \\
9. & 12,0 & 6,30 & 3,79 & 5,28 & 4,09 & 5,57 \\
10. & 14,0 & 5,05 & 3,17 & 4,56 & 3,36 & 5,01 \\
11. & 16,0 & 4,83 & 2,74 & 3,94 & 2,85 & 4,38 \\
12. & 24,0 & 3,34 & 1,51 & 2,33 & 1,37 & 2,78 \\
13. & 28,0 & 2,61 & 1,15 & 1,84 & 1,11 & 2,28 \\
14. & 32,0 & 2,15 & 0,95 & 1,43 & 0,84 & 1,76 \\
15. & 36,0 & 1,70 & 0,72 & 1,14 & 0,59 & 1,41 \\
\hline
\end{tabular}

Tabel 3. Harga parameter farmakokinetika (AUC, Cp maks, $t$ maks, $K \& \mathrm{t} 1 / 2$ ) teofilina serum dari masing-masing subyek pada pemberian tablet teofilina pelepasan terkendali dosis $300 \mathrm{mg}$

\begin{tabular}{ccccccc}
\hline No. & Subyek & $\begin{array}{c}\text { AUC } \\
(\boldsymbol{\mu g} / \mathbf{m l} \mathbf{j a m})\end{array}$ & $\begin{array}{c}\text { Cp maks } \\
(\boldsymbol{\mu g} / \mathbf{m l})\end{array}$ & $\begin{array}{c}\text { t maks } \\
(\mathbf{j a m})\end{array}$ & $\begin{array}{c}\mathbf{K} \\
(\mathbf{j a m}-\mathbf{1})\end{array}$ & $\begin{array}{c}\mathbf{t} \mathbf{1} \mathbf{2} \\
(\mathbf{j a m})\end{array}$ \\
\hline 1. & KW & 114,19 & 7,15 & 4 & 0,086 & 8,03 \\
2. & DK & 79,70 & 5,03 & 4 & 0,088 & 7,84 \\
3. & SC & 96,09 & 3,96 & 4 & 0,060 & 11,52 \\
4. & WG & 100,29 & 7,18 & 4 & 0,085 & 8,12 \\
\hline & Rentang & $\mathbf{7 9 , 7 0 - 1 1 4 , 9}$ & $\mathbf{3 , 9 6 - 7 , 1 8}$ & $\mathbf{4}$ & $\mathbf{0 , 0 6 0 - 0 , 0 8 8}$ & $\mathbf{7 , 8 4 - 1 1 , 5 2}$ \\
& X & $\mathbf{9 7 , 5 6}$ & $\mathbf{5 , 8 3}$ & $\mathbf{4}$ & $\mathbf{0 , 0 8 0}$ & $\mathbf{8 , 8 7}$ \\
& SD & $\mathbf{1 4 , 2 0}$ & $\mathbf{1 , 6 0}$ & & $\mathbf{0 , 0 1 3}$ & $\mathbf{1 , 7 7}$ \\
\hline
\end{tabular}

Tabel 4. Harga parameter farmakokinetika (AUC, Cp maks, $t$ maks, $K$ \& $t 1 / 2$ ) teofilina serum dari masing-masing subyek pada pemberian tablet aminofilina pelepasan terkendali dosis $350 \mathrm{mg}$

\begin{tabular}{ccccccc}
\hline No. & Subyek & $\begin{array}{c}\text { AUC } \\
(\boldsymbol{\mu g} / \mathbf{m l} \mathbf{~ j a m})\end{array}$ & $\begin{array}{c}\text { Cp maks } \\
(\boldsymbol{\mu g} / \mathbf{m l})\end{array}$ & $\begin{array}{c}\text { t maks } \\
(\mathbf{j a m})\end{array}$ & $\begin{array}{c}\mathbf{K} \\
\left(\mathbf{j a m}^{-1}\right)\end{array}$ & $\begin{array}{c}\mathbf{t} \mathbf{1} \mathbf{2} \\
(\mathbf{j a m})\end{array}$ \\
\hline 1. & FR & 150,49 & 6,63 & 8,0 & 0,056 & 12,38 \\
2. & WJ & 93,31 & 5,35 & 6,0 & 0,060 & 11,55 \\
3. & RR & 131,20 & 7,30 & 6,0 & 0,060 & 11,55 \\
4. & WB & 105,77 & 7,73 & 6,0 & 0,070 & 9,90 \\
5. & RX & 128,89 & 6,48 & 8,0 & 0,057 & 12,16 \\
\hline & Rentang & $\mathbf{9 3 , 3 1 - 1 5 0 , 4 9}$ & $\mathbf{5 , 3 5 - 7 , 7 3}$ & $\mathbf{6 , 0 - 8 , 0}$ & $\mathbf{0 , 0 5 6 - 0 , 0 7 0}$ & $\mathbf{9 , 9 0 - 1 2 , 3 8}$ \\
& X & $\mathbf{1 2 1 , 9 3}$ & $\mathbf{6 , 7 0}$ & $\mathbf{6 , 8}$ & $\mathbf{0 , 0 6 1}$ & $\mathbf{1 1 , 5 1}$ \\
& SD & $\mathbf{2 2 , 5 3}$ & $\mathbf{0 , 9 1}$ & $\mathbf{1 , 1}$ & $\mathbf{0 , 0 0 6}$ & $\mathbf{0 , 9 7}$ \\
\hline
\end{tabular}




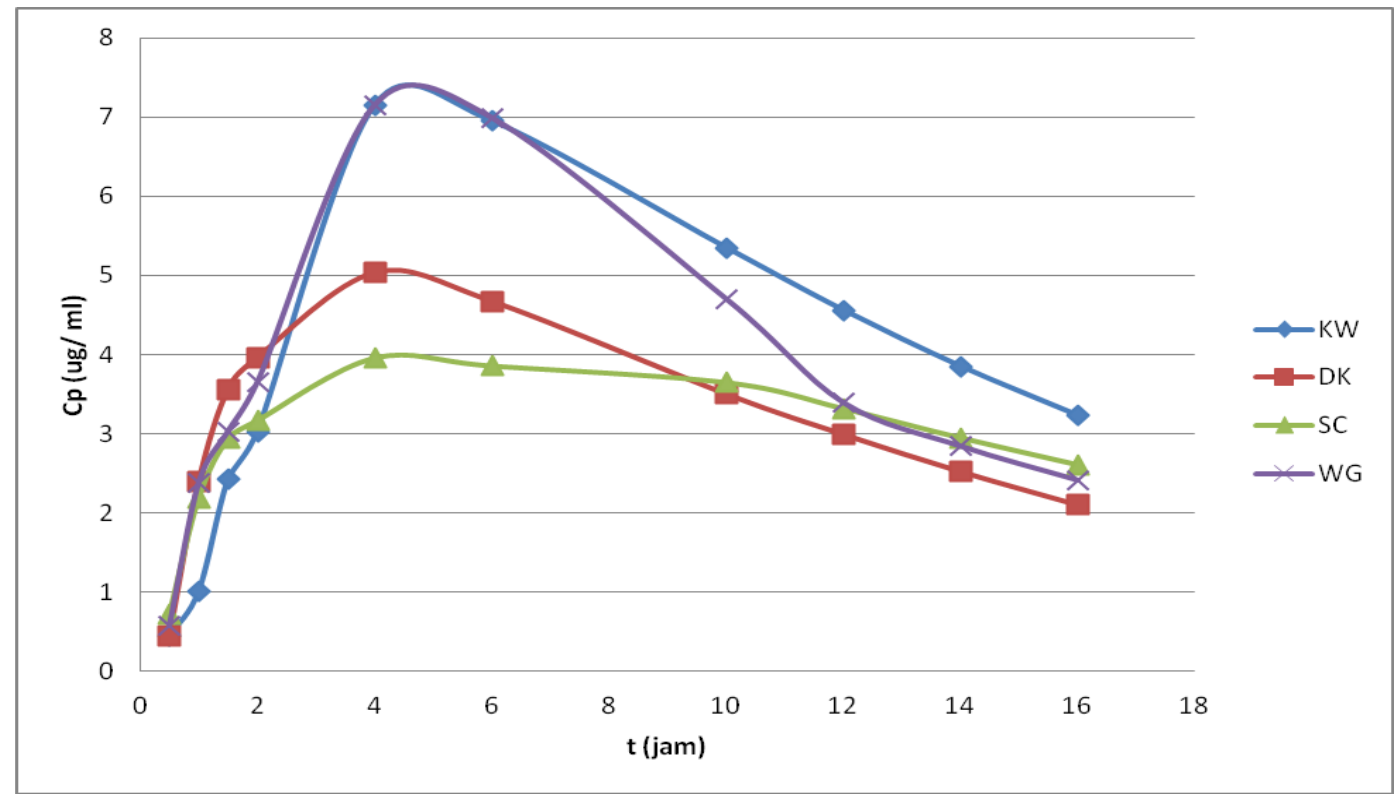

Gambar 1. Kurva kadar teofilina terhadap waktu pada pemberian tablet teofilina pelepasan terkendali dari keempat subyek

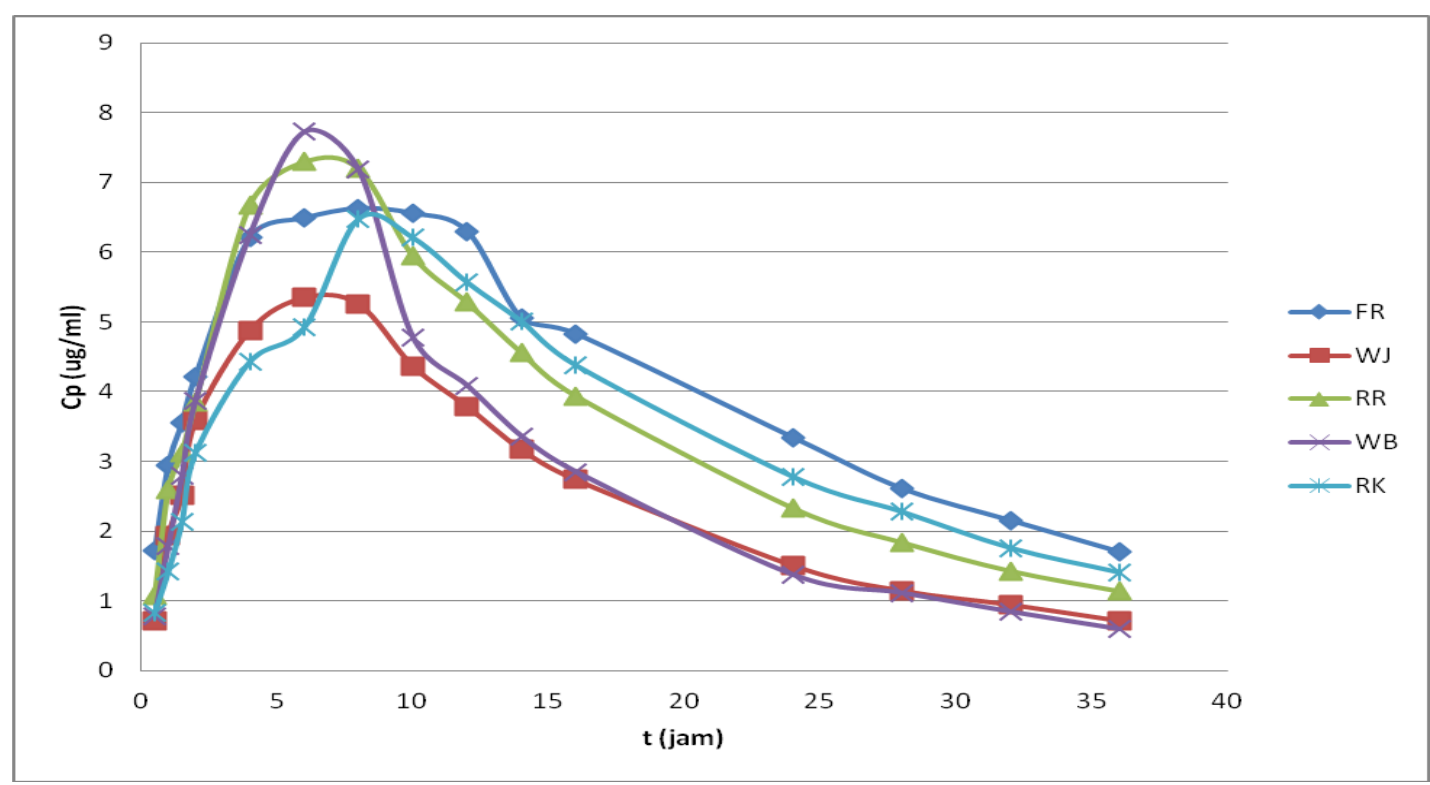

Gambar 2. Kurva teofilina terhadap waktu pada pemberian tablet aminofilina pelepasan terkendali dari kelima subyek

yaitu di atas kadar efektif minimum dan di bawah kadar toksik dan ini berada dalam waktu yang lebih lama dibandingkan pemberian tablet teofilina konvensional (Gambar 4). Waktu okupansi teofilina [2] berada pada rentang 2-8 $1 / 2$ jam (ta- blet teofilina) dan 4-13 jam (tablet aminofilina) (Tabel 7) dan ini lebih lama dibandingkan tablet konvensional.

Terdapatnya variasi kadar teofilina dalam serum dari ke sembilan subyek kemungkinan kare- 


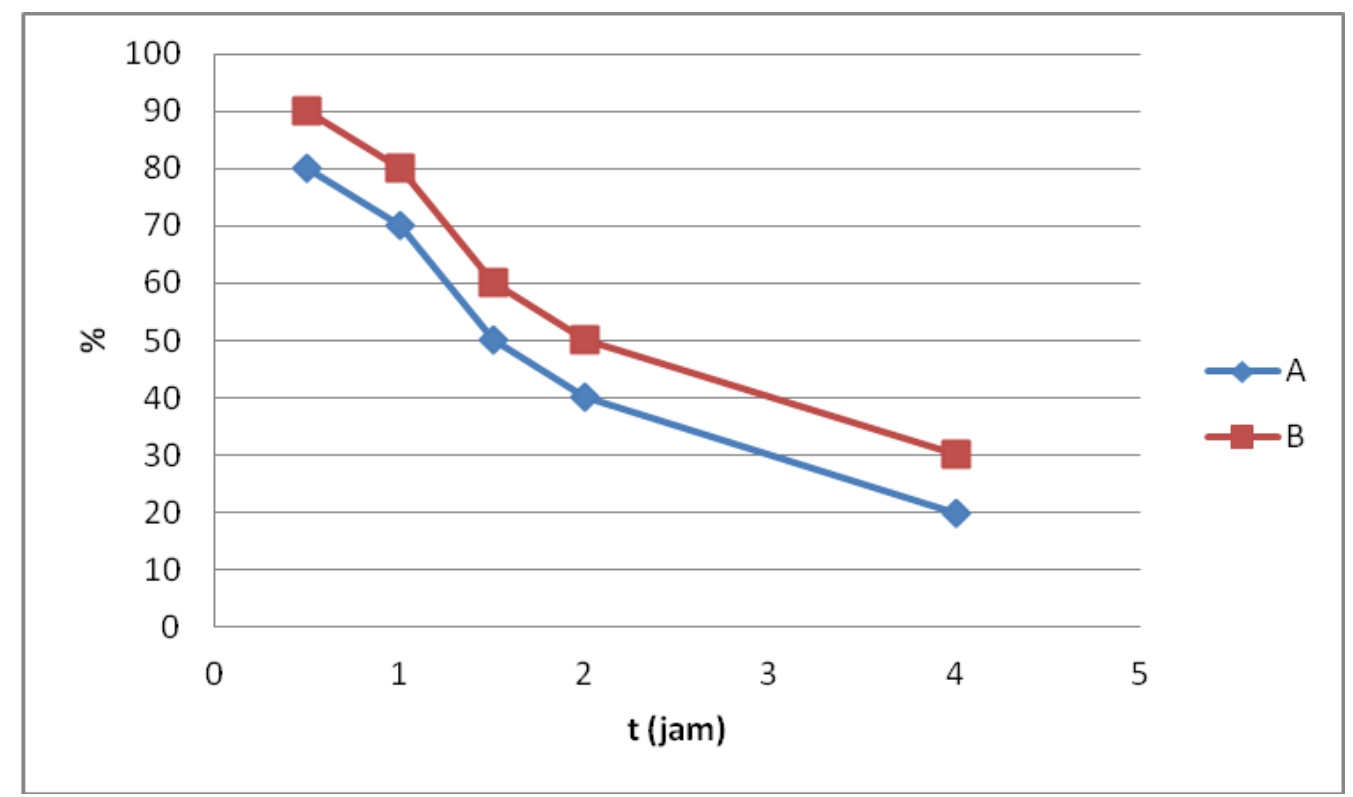

Gambar 3. Kurva fraksi yang tidak terabsorpsi teofilina terhadap waktu pada pemberian tablet teofilina (A) dan aminofilina (B)

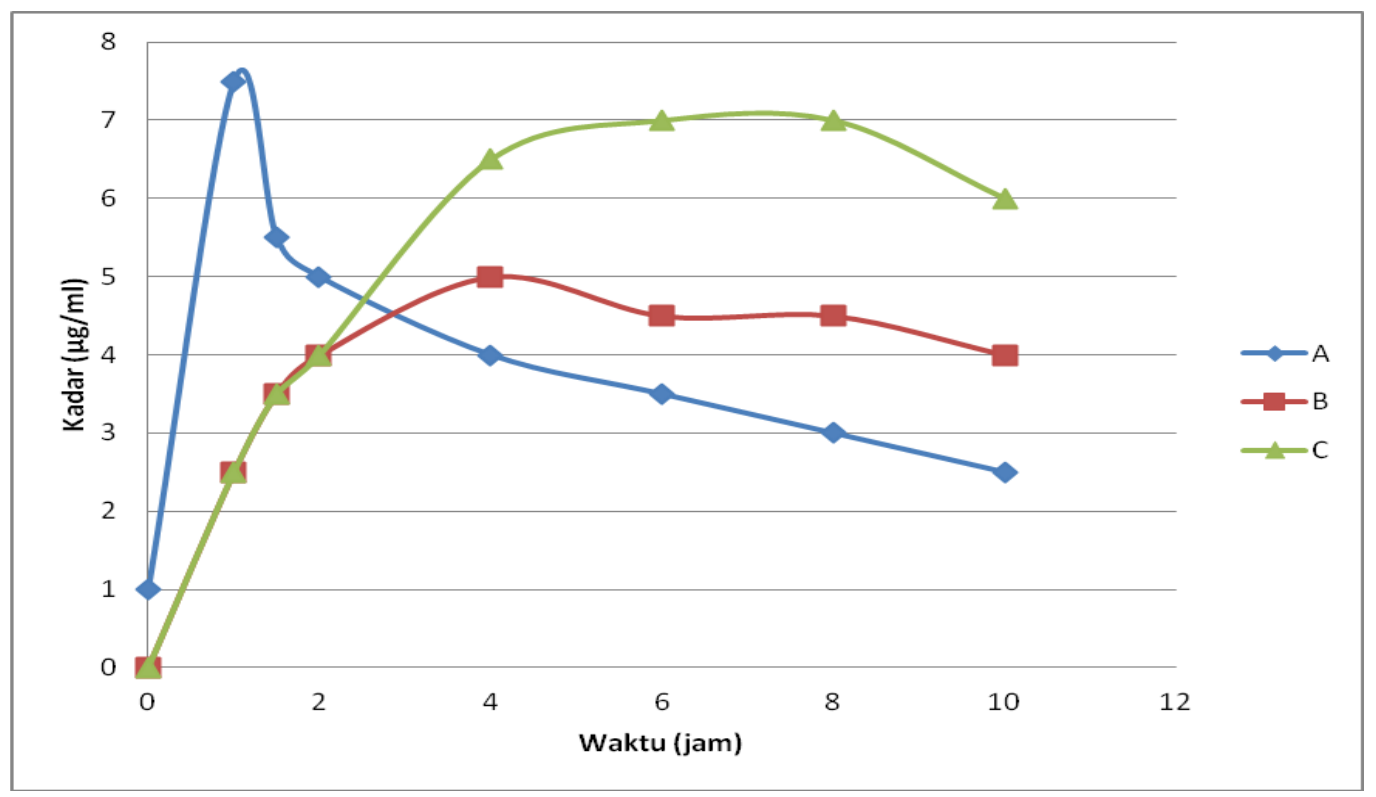

Gambar 4. Kurva kadar teofilina terhadap waktu dari tablet teofilina konvensional (A) dan teofilina (B) dan tablet aminofilina (C) pelepasan terkendali

na teofilina berada dalam bagian-bagian saluran cerna pada waktu yang cukup lama, dimana hal ini dapat dilihat pada empat jam setelah pemberian obat masih terdapat 10-15\% teofilina yang belum diabsorpsi.

Terdapat beberapa model produk obat pele- pasan terkendali [1] antara lain: produk yang hanya digunakan untuk dosis penjagaan (maintenance dose), dimana tidak terdapat dosis muatan (Initial dose, $\mathrm{DI}=0$ ), seperti halnya tablet teofilina dan aminofilina dalam penelitian ini. Dilihat dari absorpsinya yang lambat dan mula kerja obat- 
Tabel 5. Harga tetapan laju absorpsi (Ka) teofilina yang dihitung dengan metode Wagner-Nelson, pada laju order nol dan laju order satu untuk masing-masing subyek pada pemberian tablet teofilina lepas terkendali dosis $300 \mathrm{mg}$

\begin{tabular}{|c|c|c|c|c|c|}
\hline \multirow{2}{*}{ No. } & \multirow{2}{*}{ Nama } & \multicolumn{2}{|c|}{ Order nol } & \multicolumn{2}{|c|}{ Order satu } \\
\hline & & Ka (\%/ jam) & $\mathbf{r}$ & ka $\left(\right.$ jam $\left.^{-1}\right)$ & $\mathbf{r}$ \\
\hline 1. & KW & 0,232 & 0,996 & 0,530 & 0,972 \\
\hline 2. & DK & 0,210 & 0,933 & 0,576 & 0,998 \\
\hline 3. & SC & 0,169 & 0,919 & 0,398 & 0,987 \\
\hline 4. & WG & 0,227 & 0,996 & 0,618 & 0,976 \\
\hline \multicolumn{2}{|r|}{ Rentang } & \multicolumn{2}{|c|}{$0,169-0,232$} & \multicolumn{2}{|c|}{$0,398-0,618$} \\
\hline \multicolumn{2}{|r|}{$\mathbf{X}$} & \multicolumn{2}{|c|}{0,209} & \multicolumn{2}{|c|}{0,531} \\
\hline \multicolumn{2}{|r|}{ SD } & \multicolumn{2}{|c|}{0,029} & \multicolumn{2}{|c|}{0,095} \\
\hline
\end{tabular}

$\%$ adalah fraksi obat yang belum terabsorpsi

Tabel 6. Harga tetapan laju absorpsi (Ka) teofilina yang dihitung dengan metode Wagner-Nelson, pada laju order nol dan laju order satu untuk masing-masing subyek pada pemberian tablet aminofilina lepas terkendali dosis $350 \mathrm{mg}$ teofilina lepas terkendali dosis $300 \mathrm{mg}$

\begin{tabular}{|c|c|c|c|c|c|}
\hline \multirow{2}{*}{ No. } & \multirow{2}{*}{ Nama } & \multicolumn{2}{|c|}{ Order nol } & \multicolumn{2}{|c|}{ Order satu } \\
\hline & & Ка (\%/ jam) & $\mathbf{r}$ & ka $\left(\right.$ jam-1) $\left.^{-1}\right)$ & $\mathbf{r}$ \\
\hline 1. & FR & 0,144 & 0,992 & 0,287 & 0,999 \\
\hline 2. & WJ & 0,487 & 0,975 & 0,594 & 0,996 \\
\hline 3. & $\mathrm{RR}$ & 0,197 & 0,995 & 0,489 & 0,985 \\
\hline 4. & WB & 0,228 & 0,995 & 0,655 & 0,986 \\
\hline 5. & RK & 0,138 & 0,986 & 0,220 & 0,995 \\
\hline \multicolumn{2}{|r|}{ Rentang } & \multicolumn{2}{|c|}{$0,138-0,487$} & \multicolumn{2}{|c|}{$0,220-0,655$} \\
\hline \multicolumn{2}{|r|}{$x^{\circ}$} & \multicolumn{2}{|c|}{0,239} & \multicolumn{2}{|c|}{0,450} \\
\hline \multicolumn{2}{|r|}{ SD } & \multicolumn{2}{|c|}{0,144} & \multicolumn{2}{|c|}{0,190} \\
\hline
\end{tabular}

$\%$ adalah fraksi obat yang belum terabsorpsi

Tabel 7. Mula dan lama kerja teofilina pada pemberian tablet teofilina pada pemberian tablet teofilina (300 $\mathrm{mg}$ ) dan aminofilina $(350 \mathrm{mg}$ ) pelepasan terkendali pada masing-masing subyek

\begin{tabular}{cccccc}
\hline Teofilina & \multicolumn{5}{c}{ Aminofilina } \\
\hline Subyek & $\begin{array}{c}\text { Mko } \\
\text { (jam) }\end{array}$ & $\begin{array}{c}\text { Iko } \\
\text { (jam) }\end{array}$ & Subyek & $\begin{array}{c}\text { Mko } \\
\text { (jam) }\end{array}$ & $\begin{array}{c}\text { Iko } \\
\text { (jam) }\end{array}$ \\
\hline KW & 3,0 & 8,5 & FR & 3,0 & 13,0 \\
DK & 3,0 & 2,0 & WJ & 4,0 & 4,0 \\
SC & --- & --- & RR & 3,0 & 11,0 \\
WB & 2,5 & 7,5 & WB & 3,0 & 7,0 \\
& & & RK & 6,0 & 8,0 \\
\hline
\end{tabular}

Mko = mula kerja obat (jam); Iko = lama kerja obat $(j a m)$

nya (2 $1 / 2-3$ jam) untuk tablet teofilina dan (3-6 jam) untuk tablet dosis muatan teofilina. Untuk merencanakan dosis muatan dalam pelepasan terkendali dibutuhkan data klirens teofilina dan kadar efektif minimum yang dikehendaki $\mathrm{D}=\mathrm{Cp}$. b. Cl. dan rancangan laju absorpsi= laju eliminasi yaitu, R=MEC.Vd.K, laju absorpsi lebih lambat daripada tablet konvensional begitu juga untuk $\mathrm{t}$ maks, sehingga kadar obat dalam serum terlihat lebih dapat dipertahankan, $\mathrm{t}$ maks teofilina tablet konvensional pada umumnya satu jam karena teofilina mudah larut di dalam asam lambung [3]. 
MRT untuk tablet teofilina konvensional kurang lebih 1,5 jam sedangkan tablet teofilina lepas kendali antara 12,5 sampai 16,5 jam. Hal tersebut menggambarkan tablet lepas kendali lebih dapat mempertahankan kadar obat dalam serum.

Harga tetapan laju eliminasi dan waktu paruh eliminasi yang dihasilkan sama dengan harga tetapan laju eliminasi dan waktu paruh eliminasi teofilina dalam tablet konvensional (antara 6 sampai 12 jam), hal ini menunjukkan bahwa parameter tersebut tidak dipengaruhi oleh bentuk sediaan [1].

\section{Kesimpulan}

Dari hasil penelitian yang telah dilakukan dapat disimpulkan sebagai berikut: Profil kurva kadar teofilina serum terhadap waktu pada tablet teofilina (dengan parameter AUC $=97,56 \mu \mathrm{g} / \mathrm{ml}$ jam, Cp maks $=5,83 \mu \mathrm{g} / \mathrm{ml}$, t maks $=4$ jam, $\mathrm{K}=0,080$ jam $^{-1}, \mathrm{t}^{1} \frac{1}{2}=8,87$ jam) dan aminofilina lepas kendali (dengan parameter AUC $=121,93 \mu \mathrm{g} / \mathrm{ml} \mathrm{jam}$, $\mathrm{Cp}$ maks=6,70 $\mu \mathrm{g} / \mathrm{ml}, \mathrm{t}$ maks $=6,8$ jam, $\mathrm{K}=0,061$ $\mathrm{jam}^{-1}, \mathrm{t} 1 \frac{1}{2}=11,51$ jam) sesuai dengan profil farmakokinetika sediaan lepas kendali pada umumnya.

\section{Ucapan Terimakasih}

Ucapan terimakasih kami sampaikan kepada:

1. Para volunter

2. Laboratorium klinik Prodia Surabaya
3. PT. Abbot Jakarta

4. Fakultas Farmasi Universitas Surabaya

\section{Daftar Pustaka}

1. DiPiro JT, et all. Concepts in Clinical Pharmacokinetics, 2nd ed. American Society of Health-System Pharmacist Inc; 1996.

2. Hubeis AA. Teofilina Studi Eksperimental Profil Farmakokinetik, Ringkasan Disertasi. Surabaya: Airlangga University Press; 1983.

3. Shargel L, Yu ABC. Applied Biopharmaceutics and Pharmacokinetis, 16th ed. New York: Mc Graw Hill Medical; 2012.

4. Rowland M, Tozer TN. Clinical Pharmacokinetics and Pharmacodynamics:Concepts and application, 4th edition. Philadelphia: Lippincot Williams \& Wilkins; 2011.

5. Wagner JG. Fundamentals of Clinical Pharmacokinetics, 2nd Printing. Illinois: Drug Intelligence Publications Inc.; 1979.

6. Jolley ME, et all. Flourescence Polarization Immunoassay III, An Automated System For Therapeutic Drug Determination. Clinical Chemistry. 1981;27(9):1575-9.

7. Badan Pengawas Obat dan Makanan Republik Indonesia. Pedoman Metodologi Uji Bioekuivalensi. 2015.

8. Badan Pengawas Obat dan Makanan Republik Indonesia. Pedoman Metodologi Uji Bioekuivalensi Spesifik Zat Aktif. 2015.

9. Badan Pengawas Obat dan Makanan Republik Indonesia. Pedoman Cara Uji Klinik yang Baik di Indonesia. 2015. 